\title{
Neuropsychological assessment of a preteen with conduct disorder
}

\author{
María Rocío Acosta, Juliana Triana, Alexandra Gaitán Chipatecua, Luisa Fonseca and Diana \\ Alonso \\ Universidad de San Buenaventura, Bogotá, DC, Colombia
}

\begin{abstract}
The main objective of this article was to describe the neuropsychological performance of a preteen diagnosed with attentiondeficit/hyperactivity disorder according to the Diagnostic and Statistical Manual of Mental Disorders, 4th edition (DSM-IV). An average level of intelligence but poor attention, memory, and language performance and executive function were found during the neuropsychological assessment. We also found significant detriments at the behavioral level that corresponded to the DSM-IV diagnosis. These results are consistent with studies of patients with frontal lobe dysfunction in which females with conduct disorder present a neuropsychological profile with greater compromises in cognitive processes. Consequently, the present text highlights the importance of obtaining a greater empirical and theoretical background for diagnosis and early intervention to reduce the social consequences of female criminality. Keywords: frontal lobe; conduct disorder; neurobehavioral manifestations; executive function.
\end{abstract}

Received 10 October 2011; received in revised form 2 March 2012; accepted 20 April. Available online 29 June 2012.

\section{Introduction}

In Latin America the psychosocial impact of behavioral alterations exhibited by children and adolescents is becoming more relevant. The rates of domestic and social violence that they perpetrate are alarming. A study by Sanabria and Uribe (2009) found that cases of criminal conduct perpetrated by persons younger than 18 years of age doubled in the past decade. Cruz and Rodríguez (2009) observed a similar situation in Central and South America and established a relationship between child and adolescent violence and social exclusion variables.

Among these behavioral alterations, conduct disorder presents behavioral signs and symptoms that may predict adult violence, a problem with high social and economic costs and consequences that cannot be ignored (Krug, Dahlberg, Mercy, \& Lozano, 2002). The prevalence of conduct disorder is high and has increased in recent years, ranging from $4 \%$ to $7 \%$ and leading to greater socioeconomic failure in Latin America (Clark, Prior, \& Kinsella, 2002; Morrell \& Murray, 2003).

María Rocío Acosta, Juliana Triana, Alexandra Gaitan Chipatecua, Luisa Fonseca, Diana Alonso, Universidad de San Buenaventura, Bogotá, Colombia. Correspondence regarding this article should be directed to: María Rocío Acosta Barreto, Universidad de San Buenaventura, Carrera $8 \mathrm{H}$ No. 172-20, Faculty of Psychology, Neuropsychology Master and Specialization Program, Bogotá, Colombia. E-mail: rocioacosta93@yahoo.com
According to the World Health Organization (1992), the prevalence of conduct disorder in male adolescents ranges from $6 \%$ to $16 \%$ and in females ranges from $2 \%$ to $9 \%$, depending on the region. Avery-Leaf, Cascardi, O'Leary, and Cano (1997) reported a 21.4\% prevalence of violent behavior in adolescent males and a $52.9 \%$ prevalence in females. The Secretaría de Salud de México (2002) noted a prevalence of $67 \%$ in both males and females. The National Mental Health Survey conducted in Colombia in 2003 (Posada-Villa, Aguilar-Gaxiola, Magaña, \& Gómez, 2004) found a prevalence of conduct disorder of $8.8 \%$ in males and $2.7 \%$ in females, with an average age of onset of 10 years (Sanabria \& Uribe, 2007).

Although making no gender distinctions, attempts to explain behavioral disorders in children and adolescents have referred to social, cultural, and genetic vulnerability that may be associated with prefrontal dysfunction or connections between prefrontal and limbic systems and other cortical and subcortical structures (Rey, 2010). From a neuropsychological perspective, the role of the frontal lobe in the regulation and development of behavioral strategies, including inhibition and emotional control that allow an individual to actively and successfully interact in a social community, has been established. Neuropsychological and neuroimaging studies have shown that behavioral and emotional regulation is compromised when these areas are damaged by acquired brain injury or maturation disorders (Kim, Kim, \& Kwon, 2001; Murray-Close, 
Crick, \& Galotti, 2006; Serper, Beech, Harvey, \& Dill, 2008; Barnett, Maruff, \& Vance, 2009).

However, few studies have investigated the differences between males and females with frontal lobe damage. Moffit (1988) and Yeudall, Fedora, Fedora, \& Wardell (1982) (cited by Darbra \& Martrí, 1998) stated that dysfunction in frontal areas in females alters moral conduct and causes the recurrence of behaviors such as coldness and cognitive and behavioral inflexibility. Darbra and Martrí (1998) also argued that males are more susceptible to environmental factors, whereas females have greater genetic vulnerability to develop antisocial behavior. This would predispose females to the generation and maintenance of disruptive behaviors compared with males and render them less socially readaptable.

Some studies indicated that ventral frontal injury acquired during childhood generates moral and behavioral abnormalities similar to those in persons with antisocial behavior (Ostrosky-Solís, 2008). Damasio (2000) argued that right ventral and dorsolateral prefrontal damage is associated with a deterioration in moral decision-making in which patients who do not dissociate social cognition and moral knowledge have no consistency in their understanding or moral rules and behaviors.

Importantly, early frontal lesions that occur during human development (i.e., before the age of 16 months) produce more serious social and moral developmental disorders compared with cases when the injury occurs in adulthood, partially because the individuals never acquired formal rules of moral conduct. A study by Best, Miller, and Jones (2009) associated emotional control with social functioning. These authors stated that executive function assists in attentional control (i.e., the ability to focus and shift attention), inhibitory control (i.e., the ability to plan future actions and inhibit inappropriate responses), and low-intensity pleasure derived from activities that have low novelty, complexity, and intensity. Damage in executive function as confirmed by neuropsychological tests decreases the level of control in these three areas to varying degrees. Moreover, other cognitive functions such as memory can be secondarily affected (Trujillo, Pineda, \& Puerta, 2001).

Neuropsychological studies have reported difficulties in a wide range of cognitive skills, including those associated with frontal functions that are important for cognitive functioning, emotional control, and social interaction (Bauer \& Hesselbrock, 2001; Gioia, Isquith, \& Guy, 2001; Anderson, Anderson, Northam, Jacobs, \& Mikiewicz, 2002; Anderson \& Doyle, 2004; Mahone \& Wodka, 2008; Rey, 2010). Navas-Collado \& MuñozGarcía (2004) concluded that the neuropsychological evaluations of patients with a history of compromised behavior and frontal dysfunction reveal marked difficulties in concentration; a need for external mediation to complete a task; problems learning new processes; cognitive inflexibility; poor abstraction, categorization, and planning performance; and a high tendency to be impulsive, with changes in their character and volition.

As mentioned above, results of neuropsychological studies have not reported dissociable gender performance. This aspect needs to be addressed in depth, given the different profiles. Thus, the present article describes the neuropsychological performance of a preadolescent psychologically and psychiatrically diagnosed with Attention Deficit Disorder with comorbid hyperactivity and Conduct Disorder according to the Diagnostic and Statistical Manual of Mental Disorders, 4th edition (DSM-IV). The formulated hypothesis was that neuropsychological disorders in a female are markedly evident in more than one cognitive process.

\section{Case Report \\ Design}

This was a case study design (Capitani \& Laiacona, 2000) that neuropsychologically assessed a single subject and compared the results with normative data. The case study did not focus entirely on statistical analyses because it sought to establish a reference to consider other neuropsychological assessments in preteens and more generally in females with conduct disorder.

\section{Subject}

The subject was an 11-year-, 8-month-old preteen female with right-hand laterality from Bogotá, Colombia. Her level of education was the fifth grade, and she was currently deprived of schooling at the time of assessment. She was the product of a second high-risk pregnancy when her mother, who was 20 years old, consumed high doses of nicotine and suffered from hyperemesis gravidarum. At 25 weeks of gestation, her mother underwent premature labor, and the subject was born at 32 weeks of gestation. Childbirth occurred by cesarean section, and the baby girl was born with a low birth weight.

When the subject was 8 days old, she was hospitalized for bronchopneumonia. As a newborn, she cried a lot, had high levels of anxiety, was restless, and did not like being held. She exhibited affective responsiveness to her mother at 2 months of age, rolled over at 3 months of age, sat at 5 months of age, babbled at 5 months of age, pronounced her first words at 7 months of age, and pronounced semi-structured words at 8 months of age. She did not crawl but began walking at 11 months of age. During her first 4 years, she had respiratory problems and exhibited primary enuresis until the age of 10 , the same age at which her menarche occurred.

At the time of assessment, her parents were separated. She lived with her extended family, with a stronger filial bond with her grandmother. Her father had a criminal record and was incarcerated. The father had behavioral dysfunction, poor academic performance, aggression, and impulsivity. The family history included a maternal uncle who presented paranoid-type schizophrenia that began after consuming psychoactive substances. 
With regard to self-care, the girl did not have adequate habits. She was unconcerned about cleanliness and grooming. Behaviorally, she committed misdemeanors, had episodes of self-harm, and had poor interpersonal relations (i.e., conflicts with peers). She was irritable, easily lost emotional control, tended to cry when confronted with failure, had tantrums, often broke things when she was upset, and escaped from home. Early sexual awakening, promiscuity, and inadequate management of contraception and protection were also reported.

The mother applied corporal punishment to the point of physical abuse in her attempt to control the minor, resulting in an increase in fleeing and aggressiveness toward others. The subject's behavioral situation worsened during the past 2 years. She carried sharp weapons and expressed verbal and physical aggression toward her family, peers, and teachers.

At the academic level, she adapted quickly to kindergarten but often beat her peers. She had poor academic performance from the beginning of schooling and was highly disinterested in studying and homework. The mother reported that she was easily distracted and had several school transfers because of behavioral difficulties.

\section{Instruments}

A semi-structured interview was conducted with the mother and preteen. The following tests were used for the neuropsychological assessment:

- Weschler Intelligence Scale for Children (WISCIV): This instrument provides overall, verbal, and manipulative intelligence quotients (IQs). It also is a reliable measure of intellectual functioning in children between 6 and 16 years of age. The WISC-IV has four main indices: verbal comprehension index, perceptual reasoning index, working memory, and processing speed index. The reliability of the WISCIV composite scales varies from .88 to .97 (Weiss, Saklofske, Prifitera, \& Holdnack, 2006).

- Auditory and Visual Continuous Performance Test: This instrument assesses selective, focused, and divided attention in tasks that require continuous work that the subject must perform monotonously without pausing (Rosvold, Misky, Sarason, Bransome, \& Beck, 1956).

- Trail Making Test, forms A and B (TMT-A and TMT-B): Part A of this instrument assesses sustained attention, and Part B assesses divided attention. The instrument was designed by Partington and Leiter (1938) and then incorporated into the Halstead-Reitan Neuropsychological Test Battery. The reliability of the TMT-A is between .76 and .89 , and the reliability of the TMT-B is between .86 and .94 (Rabin, Barr, \& Burton, 2005).

- Ardila and Ostrosky's Verbal Memory Curve: This instrument assesses verbal memory using a list of 10 words that are shown to the subject until the subject recalls all of the words or has made 10 attempts. It rates the initial volume, maximum volume, trials, and delay recall 23 min later (Ardila \& Rosselli, 1992).

- Ardila's Visual Memory Curve: This instrument assesses visual memory using a sheet with 10 simple figures that are successively presented until they are completely memorized. The subject is asked to recall these 3 and 23 min later (Ardila \& Rosselli, 1992).

- Semantic memory with associative increment: This instrument explores the benefit of supplying a semantic key at the beginning of the test using two learning trials. The subject is asked to recall these 23 min later (Pineda, Galeano, \& Giraldo, 1991).

- Rey-Osterrieth Complex Figure: This instrument consists of a copy trial used in subjects beginning at the age of 5 years in which the subject is asked to recall a geometric figure. In an average population, recall of at least 10 points is expected. The instrument was designed by Rey and standardized by Osterrieth (Rey \& Osterrieth, 1993).

- Token test: This instrument was designed by Spreen and Benton (1969) and modified by DeRenzie and Vignolo (1962). It evaluates language comprehension of progressively complex instructions given in relation to tokens. The evaluation ends after eight consecutive errors occur (DeRenzie \& Vignolo, 1962).

- Phonological and semantic verbal fluency test: This instrument has been referred to as a semantic paradigm and phonological paradigm (Thurstone, 1931; Newcombe, 1969; Benton, 1980). It evaluates the verbal production of words that begin with a letter (/ f/, / a /, / s /) within a semantic category (e.g., fruits and animals) under restricted conditions in relation to time (Strauss, Sherman, \& Spreen, 2006).

- Wisconsin Card Sorting Test (WCST): This instrument assesses executive function through the classification of two groups of 64-card decks under restricted conditions in relation to the evaluator's order of correct and incorrect. It is used primarily to assess perseveration and abstract thinking (Grant \& Berg, 2003).

- Stroop test: This instrument assesses the ability to change a strategy while inhibiting a common response to favor an uncommon outcome (Golden, 1994). It was designed by Stroop (1935). An evaluation with Victoria modification of Regard was used (Regard, 1981).

- Child Neuropsychological Assessment: This instrument assesses the neuropsychological characteristics of children and school-age youths (Matute, Rosselli, Ardila, \& Ostrosky-Solís 2004). In the present case study, tests of reading skills, auditory recognition, mental arithmetic, and arithmetic problems were performed.

\section{Procedure}

The preteen was admitted to the Psychological Care Centre at the University of San Buenaventura, Bogotá, Colombia to participate in behavioral referral workshops after being referred by the Instituto de Bienestar Familiar (Colombian Family Welfare Institute). This 
institute referred her to child psychiatry, psychology, and neuropsychology areas because of difficulties with peers and professionals.

The psychology and psychiatry areas concluded that she presented Attention-Deficit/Hyperactivity Disorder (Combined Type) and Oppositional Defiant Disorder (ODD) because she met the diagnostic criteria of the DSM-IV. The neuropsychology area requested signed informed consent from the mother and preteen. A semistructured interview was conducted with the mother and subject separately to investigate the reason for the consultation, learn her personal background, and hear specific clinical complaints. The minor attended four assessment sessions, each $1 \mathrm{~h}$ long, and completed an institutional neuropsychological assessment protocol. The evaluation was conducted by a clinician with an MSc degree in neuropsychology accompanied by two students in neuropsychology graduate programs at the University of San Buenaventura, Bogotá, who were observers of the process. The first step was a test of intelligence followed by the other tests. Finally, we performed an analysis of the results.

\section{Results}

A descriptive analysis was conducted with the preteen by applying each of the aforementioned tests. The teenager had an IQ of 90. Her verbal IQ was 93, and her manipulative IQ was 92 . Figures 1 and 2 show the scaled and composite score profiles obtained on the WISC-IV. The following tables and graphics present the cognitive process results and the scores on each of the tests. Tables $1-3$ and Figures 3-5 show the results of the attention, linguistic, executive function, verbal memory, visual memory, and semantic memory test results. The subject met the diagnostic criteria for conduct disorder (Table 4).

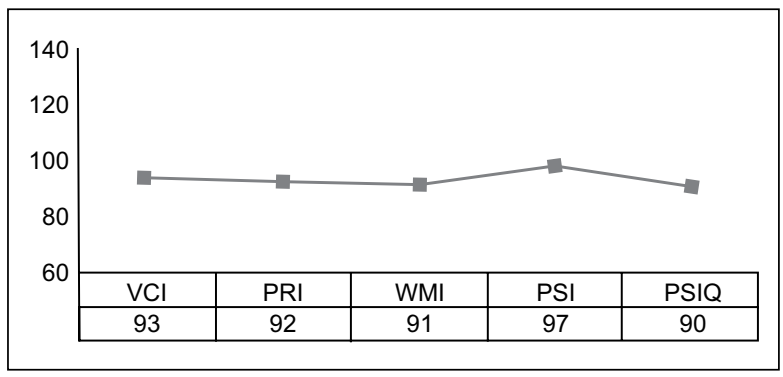

Figure 2. WISC-IV composite scores. VCI, verbal comprehension index; PRI, perceptual reasoning index; WMI, working memory index; PSI, processing speed index; PSIQ, Processing Speed IQ.

\section{Discussion}

The present article describes the neuropsychological performance of a preteen with conduct disorder. The patient had preserved global cognitive functioning but obvious difficulties in several cognitive domains. With regard to her intelligence profile, a remarkably low score on concepts was found. This subtest is part of perceptual reasoning and could indicate potential problems learning new material when dealing with abstract concepts. With regard to attention, difficulties were found in the inhibition of environmental stimuli or her own thinking and a failure to maintain focus during lengthy tasks. With regard to mnemonic function, an adequate capacity to learn the verbal component ( $75 \%$ of learning) and visual component ( $77 \%$ of learning) was found. However, she presented poor long-term recall because of weaknesses in organization during storage, attentional failures, and difficulty creating metamemory strategies. With regard to gnosis and praxis, flaws were notable in the planning of the execution of movements required to complete a task efficiently. With regard to language, the subject presented poor understanding of complex verbal instructions, repetition, and fragmentation to

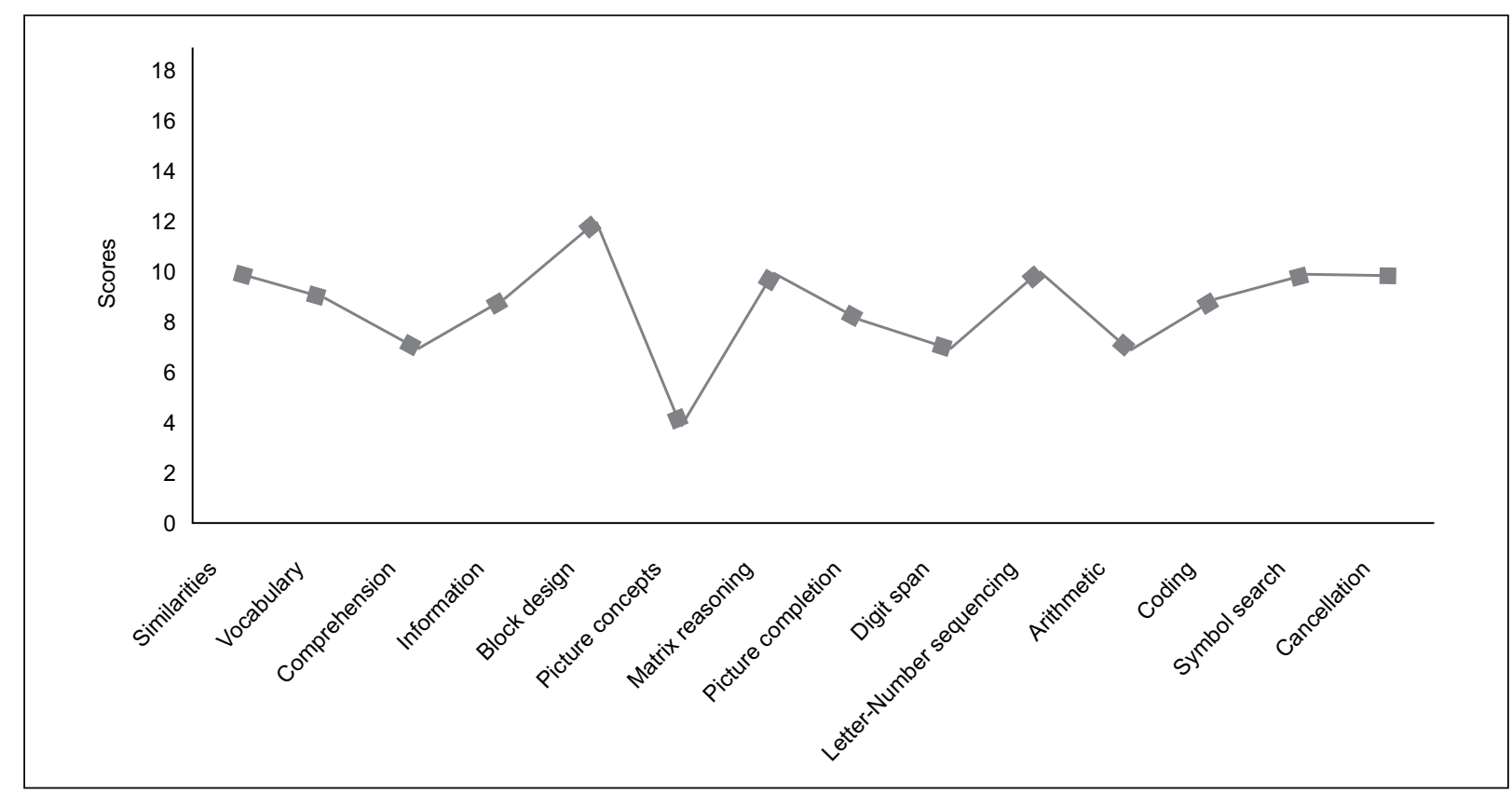

Figure 1. WISC-IV subtest scale scores. 
Table 1. Attention test scores

\begin{tabular}{llll}
\hline Test & Results & Standard scores & Description of performance \\
\hline Auditory cancellation & $\begin{array}{l}\text { Omissions: } 0 \\
\text { Commissions: } 0\end{array}$ & $\begin{array}{l}\text { Omissions: } 0 \\
\text { Commissions: } 0\end{array}$ & Average \\
Visual cancellation & $\begin{array}{l}\text { Time: } 43 \mathrm{~s} \\
\text { Omissions: } 0 \\
\text { Commissions: } 0\end{array}$ & $\begin{array}{l}\text { Time: } 25 \mathrm{~s} \\
\text { Omissions: } 0 \\
\text { Commissions: } 0\end{array}$ & Greater amount of time \\
TMT-A & Time: $36 \mathrm{~s}$ & Time: $29 \mathrm{~s}$ & \\
& Errors: 0 & Errors: 0 & Greater amount of time \\
TMT-B & Time: $93 \mathrm{~s}$ & Time: $75 \mathrm{~s}$ & Greater amount of time \\
& Errors: 0 & Errors: 0 & \\
\hline
\end{tabular}

TMT, trail-making test.

Table 2. Linguistic test scores

\begin{tabular}{llll}
\hline Test & Results & Standard scores & Description of performance \\
\hline Semantic fluency & 16 & 29.7 & Poor \\
Token test & 34 & 35.2 & Average \\
Reading & Silent & Silent & \\
& Time: $42 \mathrm{~s}$ & Time: $20 \mathrm{~s}$ & Greater amount of time \\
& Comprehension: 3 & Comprehension: 6 & Poor \\
& Aloud & Aloud & Greater amount of time \\
& Time: $42 \mathrm{~s}$ & Time: $20 \mathrm{~s}$ & Average \\
& Errors: 0 & Errors: 0 & Average \\
Comprehension: 5 & Comprehension: 6 & Alteration \\
Writing & Dysorthography & & Poor \\
Mental calculation & 8 & 12 & Very poor \\
Written calculation & 2 & 7 &
\end{tabular}

Table 3. Executive function test scores

\begin{tabular}{|c|c|c|c|}
\hline Test & Results & Standard scores & Description of performance \\
\hline \multirow[t]{5}{*}{ Stroop } & $\begin{array}{l}\text { Reading: } \\
34 \text { s, Errors: } 0\end{array}$ & $\mathrm{M}=11, \mathrm{SD}=2.5$, Errors: 0 & Greater amount of time \\
\hline & Crossings: & & Greater amount of time \\
\hline & 40 s, Misses: 1 & $\mathrm{M}=13, \mathrm{SD}=2.9$, Errors: 0 & Greater amount of time \\
\hline & Conflict: & & Inhibition errors \\
\hline & 72 s, Errors: 6 & $\mathrm{M}=22.1, \mathrm{SD}=7.2$, Errors: 0 & \\
\hline Phonological fluency & 6.3 & 25.5 & Very poor \\
\hline \multirow[t]{5}{*}{ WCST } & Hits/trials: 90/128 & Hits: 64.2 & Greater number of trials to \\
\hline & Categories: 6 & Categories: 5.8 & complete the task \\
\hline & $55 \%$ conceptual level & $62.3 \%$ conceptual level & \\
\hline & Perseverations: 5 & Perseverations: 9.5 & \\
\hline & Fact: 3 & Fact: 0.2 & \\
\hline Arithmetic & 5 & 8 & Poor \\
\hline
\end{tabular}




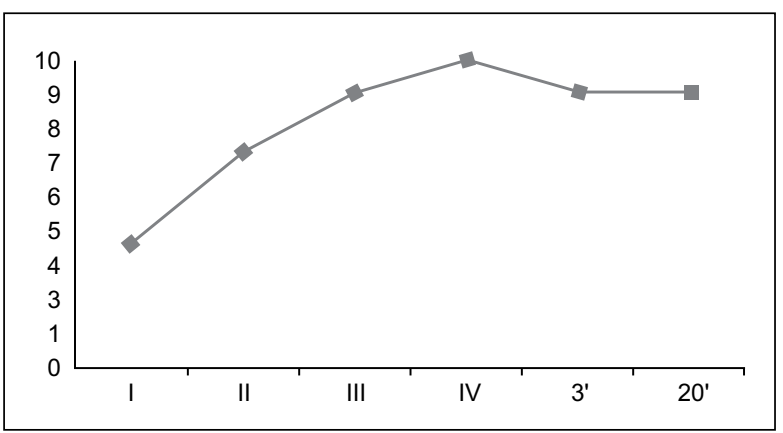

Figure 3. Verbal memory curve scores according to Ardila Verbal Learning Test.

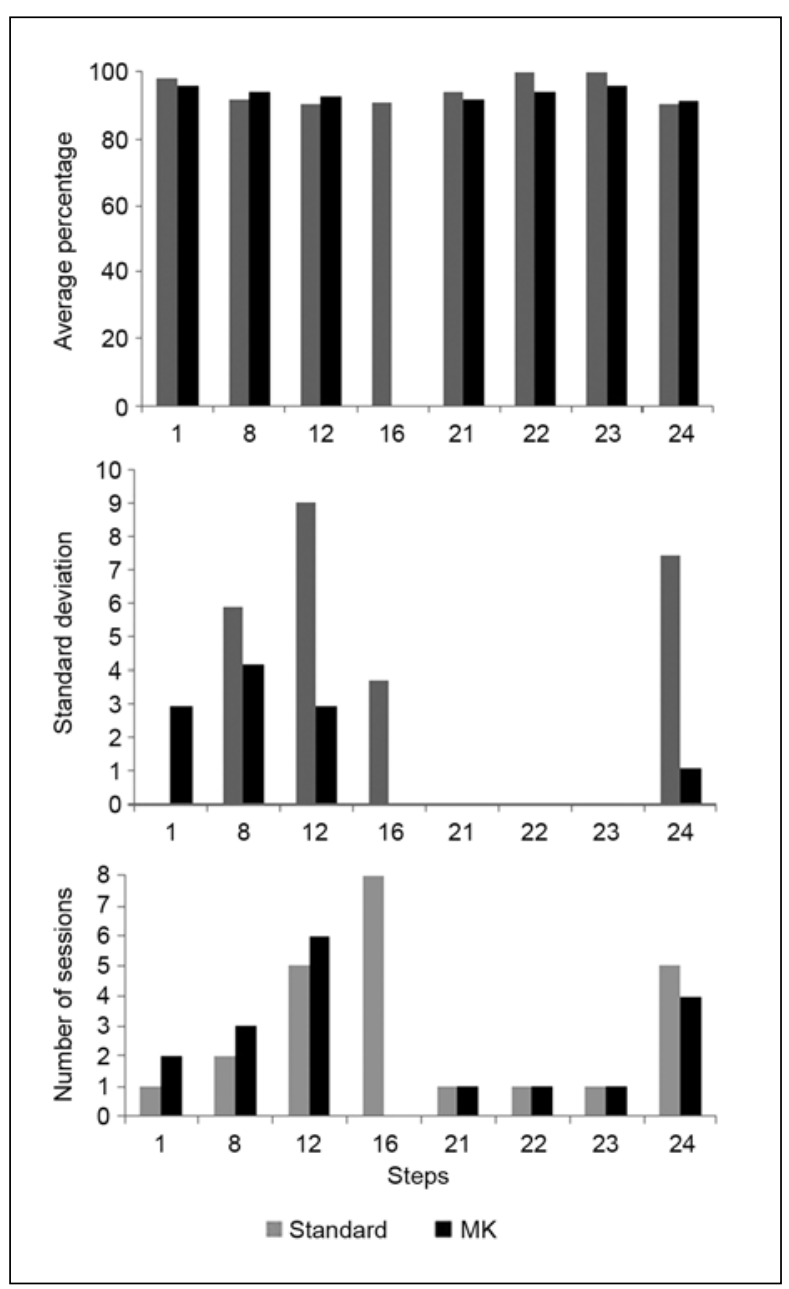

Figure 4. Ardila's visual memory curve scores according to Ardila Visual Learning Test.

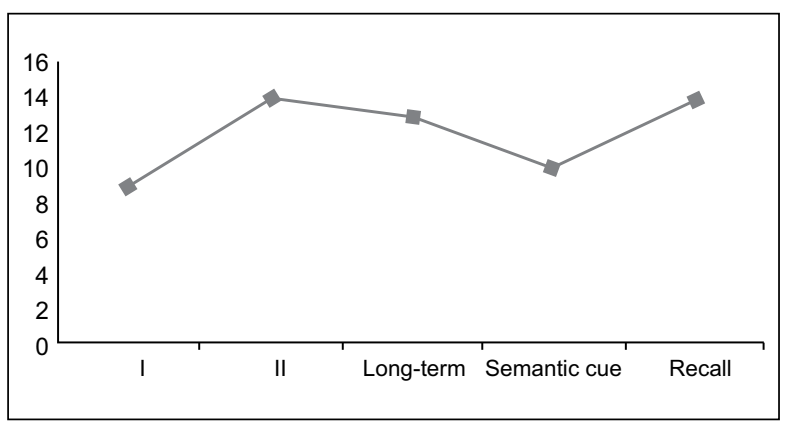

Figure 5. Semantic memory scores with associative increment.
Table 4. Diagnostic criteria fulfilled by the preteen with conduct disorder

\begin{tabular}{|c|c|}
\hline Criterion & Compliant \\
\hline \multicolumn{2}{|l|}{ A. } \\
\hline \multicolumn{2}{|l|}{ Aggression towards people and animals } \\
\hline 1. Often bullies, threatens, or intimidates others & Yes \\
\hline 2. Often initiates physical fights & Yes \\
\hline $\begin{array}{l}\text { 3. Has used a weapon that can cause serious } \\
\text { physical harm to others }\end{array}$ & Yes \\
\hline 4. Has been physically cruel to people & Yes \\
\hline 5. Has been physically cruel to animals & No \\
\hline 6. Has stolen while confronting the victim & Yes \\
\hline 7. Has forced someone into sexual activity & Yes \\
\hline \multicolumn{2}{|l|}{ Destruction of property } \\
\hline $\begin{array}{l}\text { 8. Has deliberately engaged in fire with the } \\
\text { intention to cause serious harm }\end{array}$ & No \\
\hline $\begin{array}{l}\text { 9. Has deliberately destroyed others' property } \\
\text { (other than by fire) }\end{array}$ & Yes \\
\hline \multicolumn{2}{|l|}{ Fraudulence or theft } \\
\hline $\begin{array}{l}\text { 10. Has violated the home, house, or car of another } \\
\text { person }\end{array}$ & Yes \\
\hline $\begin{array}{l}\text { 11. Often lies to obtain goods or favors or to avoid } \\
\text { fulfilling obligations }\end{array}$ & Yes \\
\hline $\begin{array}{l}\text { 12. Has stolen items of value without confronting a } \\
\text { victim }\end{array}$ & Yes \\
\hline \multicolumn{2}{|l|}{ Serious violations of rules } \\
\hline $\begin{array}{l}\text { 13. Often stays out at night despite parental } \\
\text { prohibitions, beginning this behavior before } 13 \\
\text { years of age }\end{array}$ & Yes \\
\hline $\begin{array}{l}\text { 14. Has run away from home overnight at least } \\
\text { twice while living in parental home or } \\
\text { surrogate home (or once without returning for } \\
\text { a lengthy period of time) }\end{array}$ & Yes \\
\hline $\begin{array}{l}\text { 15. Often is truant from school, beginning before } \\
13 \text { years of age }\end{array}$ & Yes \\
\hline \multicolumn{2}{|l|}{ B. } \\
\hline $\begin{array}{l}\text { The conduct disorder causes significant clinical } \\
\text { impairment in social, academic, or occupational } \\
\text { functioning }\end{array}$ & Yes \\
\hline \multicolumn{2}{|l|}{ C. } \\
\hline $\begin{array}{l}\text { Behaviors do not occur exclusively during a } \\
\text { psychotic disorder or mood disorder }\end{array}$ & Yes \\
\hline $\begin{array}{l}\text { Age of onset: Childhood } \\
\text { Severity: Moderate }\end{array}$ & \\
\hline
\end{tabular}

execute orders. This was related to weaknesses in working memory and sustained attention. In the written component she presented dysorthography, and her silent reading performance was lower than expected for her age and educational level. With regard to calculations, she had problems with analysis and operational choice. In the executive function realm, a particular weakness was found in the generation of strategies to analyze, interpret, and solve problems as well as perseverative errors and reduced phonological verbal fluency. The qualitative analysis revealed poor inhibitory control, fraudulent behaviors, and irritability when failing to persuade others.

Studies by Trujillo, Pineda, and Puerta (2001) and Navas-Collado and Muñoz-Garcia (2004) attempted to generalize the results for males and females and did not consider other factors such as genetics as mentioned by 
Darbra \& Martrí (1998). These factors may be important for conduct disorder, with females possibly having more rigid cognitive and behavioral functioning and a greater propensity for neuropsychological alterations.

With regard to behavior, sociodemographic characteristics, the subject's family history, difficulties in the school environment, verbal and physical aggression toward peers and authority figures, the bearing of knives, and other features were considered. Additionally, psychoactive substance use by the maternal uncle and the behavioral disturbances, school dropout record, and criminal record of the father were influential.

As a basis for diagnosis, diagnostic criteria of the DSM-IV for both ODD and conduct disorder were analyzed (Pichot, López-Ibor, \& Valdés, 1995). We ruled out the presence of ODD because this is primarily manifest through verbal aggression, occurs most often at home, and does not involve risk to the lives of the patient and others. In contrast, we found that the subject met the vast majority of the criteria for conduct disorder including the presence of theft, assault on others, serious rule violations, running away from home at night even though her mother had forbidden it, bearing knives, and significant impairment in social and school environments. Additionally, according to the DSM-IV, the subject's diagnosis of conduct disorder was classified as childhood-onset with mild severity because her behavioral problems caused minimal damage to others, and at least one characteristic of the disorder was present before she was 10 years old.

The present findings confirm those of Pineda and Puerta (2001). The literature reports that conduct disorder is preceded by ODD. It manifests as oppositional and defiant behavior toward parental figures and, once schooling begins, this behavior generalizes to other authority figures. The individual begins to present new dysfunctional behaviors and increase levels of aggression and social rejection. When the diagnosis of ODD is made in children and adolescents, one must first discard Behavior Disorder. If the patient meets the criteria for ODD and concurrently meets the criteria for Behavior Disorder, then one must record only a diagnosis of Behavior Disorder. In other words, the diagnosis of Behavior Disorder includes the diagnosis of ODD. In the case of a simultaneous diagnosis of Attention Deficit Disorder (ADD) and Behavior Disorder, the two diagnoses must be recorded and encoded in clinical and epidemiological studies (Pineda \& Puerta, 2001).

Another important aspect in the present case is the correlation between immaturity of the frontal lobe and inappropriate behaviors. During the assessment, high levels of impulsivity; persuasive conduct toward others; a great need to obtain answers through copying; deficiencies in comprehension and concept formation; inadequate development of strategies for analysis, interpretation, and resolution of situations; perseveration errors; low phonological verbal fluency; and poor inhibitory control were found. These signs may be related to abnormalities in the frontal lobe that have been linked to inhibition and development of behavioral strategies.

Dysfunction in frontolimbic connections has been correlated with behavioral changes (Damasio, 2000; Gioia, Isquith, \& Guy, 2001; Anderson et al., 2002; Lopera, 2008). However, this circuit is not the only one responsible for regulation and behavioral inhibition. Ventromedial and dorsolateral areas in the frontal lobe and some regions at the temporal level have been implicated in this regard. We may consider that immaturity of the frontal lobe, reflected in the neuropsychological test results, can be traced to weaknesses in the aforementioned circuits. Notably, to confirm this hypothesis, examinations that utilize functional neuroimaging techniques such as positron emission tomography are required to determine whether decreased frontal activation is present.

The brain areas involved in behavioral regulation and inhibition are not the only factors involved in the emergence of conduct disorder. Genetic factors have also been shown to have a broad impact on both behavior disorders in ADHD and conduct disorders (Swanson, 2000; Dansilio, 2008).

A study by Thapar, Button, and McGuffin (2005); see also Trujillo, Pineda, \& Puerta, 2001) found that certain conditions may precede conduct disorder and the presence of neuropsychological alterations. The severity of conduct disorder is associated with genetic susceptibility and interactions with unstructured social settings. Likewise, conduct disorder is associated with alterations in the functioning of prefrontal systems, several structures of which arise during childhood development. These authors suggested that immature regions attributable to inadequate development result in difficulties in response inhibition, failures to predict behaviors with negative consequences, exposure to dangerous situations, and a disregard for the suffering of others.

According to the results and background of the present clinical case including low socioeconomic status, academic deficiencies, familial dysfunction, inappropriate behavior (e.g., tantrums, temper outbursts, willful disobedience, tendency towards spitefulness, early sexual awakening and promiscuity, and the onset of conduct related to rule violations), it may be concluded that the subject has Behavior Disorder. Behavior Disorder added to her neuropsychological profile is consistent with immaturity of the frontal lobe and alterations in cognitive processes such as memory and language.

The limitations of this study from a research perspective include difficulty making generalizations. Preteens who have frontal lobe immaturity will not necessarily present the same neuropsychological profile as the present case. Furthermore, access to brain imaging and genetic testing was not available to establish causal relationships. Similarly, an analysis of the subject's background and diagnosis of ADHD were 
not addressed. A diagnosis of ADHD may also have been considered with conduct disorder.

Despite these limitations, the present case leads us to consider the importance of studying conduct disorder in females, which may evolve into antisocial personality disorder. Female criminality is a phenomenon that requires further studies that emphasize neurobiological mechanisms, particularly those that involve frontal areas, and neuropsychological studies with representative samples to aid in early detection and rehabilitation.

\section{References}

Anderson, P. J., \& Doyle, L. W. (2004). Executive functioning in school-aged children who were born very preterm or with extremely low birth weight in the 1990s. Pediatrics, 114, 50-57.

Anderson, V. A., Anderson, P., Northam, E., Jacobs, R., \& Mikiewicz, O. (2002). Relationships between cognitive and behavioral measures of executive function in children with brain disease. Child Neuropsychology, 8, 231-240.

Ardila, A., \& Rosselli, M. (1992). Neuropsicología clínica. Medellín: Prensa Creativa.

Avery-Leaf, S., Cascardi, M., O’Leary, K. D., \& Cano, A. (1997). Efficacy of a dating violence prevention program on attitudes justifying aggression. Journal of Adolescence Health, 21, 11-17.

Barnett, R., Maruff, P., \& Vance, A. (2009). Neurocognitive function in attention-deficit-hyperactivity disorder with and without comorbid disruptive behaviour disorders. Australian and New Zealand Journal of Psychiatry, 43, 722-730.

Bauer, L., \& Hesselbrock, V. (2001). CSD/BEM localization of P300 sources in adolescents "at-risk": Evidence of frontal cortex dysfunction in conduct disorder. Biological Psychiatry, 50, 600608.

Benton, A. L. (1980). Multilingual Aphasia Examination. AJA, Iowa.

Best, J. R., Miller, P. H., \& Jones, L. L. (2009). Executive functions after age 5: Changes and correlates. Developmental Review, 29, 180-200.

Capitani, E., \& Laiacona, M. (2000). Classification and modeling in neuropsychology: from groups to single cases. In F. Boller, \& J. Grafman (Eds), Handbook of neuropsychology, 2nd edition (pp. 53-76). Amsterdam: Elsevier.

Clark, C., Prior, M., \& Kinsella, G. (2002). The relationship between executive function abilities, adaptive behaviour, and academic achievement in children with externalizing behaviour problems. Journal of Child Psychology and Psychiatry, 43, 785-796.

Cruz, M., \& Rodríguez, R. (2009). ¿Hay diferencias políticas entre los vecinos? Políticas sociales y prevención de la violencia infantojuvenil en El Salvador y Nicaragua. Center for Latino American Studies, University of Miami, Miami, FL.

Damasio, A. R. (2000). A neural basis for sociopathy. Archives of General Psychiatry, 57, 128-129.

Dansilio, S. (2008). Procesos ejecutivos, lóbulos frontales y el espectro TDAH. fundación de neuropsicología clínica. Montevideo, Uruguay.

Darbra, S., \& Martí, S. (1998). Psicobiología de la conducta antisocial. In El sexo de la violencia: Género y cultura de la violencia. Barcelona: Icaria Editorial SA.

DeRenzi, E., \& Vignolo, L. A. (1962). The token test: A sensitive test to detect receptive disturbances in aphasics. Brain, 85, 665-678.

Gioia, G., Isquith, P., \& Guy, S. (2001). Assessment of executive function in children with neurological impairments. In R. J. Simeonsson, \& S. L. Rosenthal (Eds.), Psychological and developmental assessment children with disabilities and chronic conditions. New York: Guilford Press.

Golden, C. (1994). Stroop Test de colores y palabras. Madrid: Publicaciones de Psicología Aplicada.

Grant, D., \& Berg, E. (2003). Wisconsin Card Sorting Test. Manual. Par Inc., USA.

Kim, M. S., Kim, J. J., \& Kwon, J. S. (2001). Frontal P300 decrement and executive dysfunction in adolescents with conduct problems. Child Psychiatry and Human Development, 32, 93-106.
Krug, G., Dahlberg, L., Mercy, A., \& Lozano, R. (2002). World report on violence and health. Croatian Medical Journal, 43, 622-625.

Lopera, F. (2008). Funciones ejecutivas: Aspectos clínicos. Revista Neuropsicología, Neuropsiquiatría y Neurociencias, 8, 59-76.

Mahone, E. M., \& Wodka, E. L. (2008). The neurobiological profile of girls with ADHD. Developmental Disabilities Research Reviews, 14, 276-284.

Matute, E., Rosselli, M., Ardila, A., \& Ostrosky-Solís, F. (2004). Evaluación Neuropsicológica Infantil (ENI): Una batería para la evaluación de niños entre 5 y 16 años de edad. Revista Española de Neurología, 38, 720-731.

Moffit, T. E. (1988). Neuropsychology and self-reported early delinquency in an unselected Barth cohort: A preliminary report from New Zealand: Martinus Nijhoff.

Morrell, J., \& Murray, L. (2003). Parenting and the development of conduct disorder and hyperactive symptoms in childhood: A prospective longitudinal study from 2 months to 8 years. Journal of Child Psychology and Psychiatry, 44, 489-508.

Murray-Close, D., Crick, N. R., \& Galotti, K. M. (2006). Children's moral reasoning regarding physical and relational aggression. Social Development, 15, 345-372.

Navas-Collado, E., \& Muñoz-García, J. (2004). El síndrome disejecutivo en la psicopatía. Revista Española de Neurología, 38, 582-590.

Newcombe, F. (1969). Missile wounds of the brain: A study of psychological deficits. Oxford University Press: London

Ostrosky-Solís, F. (2008). Neurobiología de la sensibilidad moral. Revista Neuropsicología, Neuropsiquiatría y Neurociencias, 8, 115-126.

Partington, J. E. \& Leiter, R. G. (1938). Partington 's Pathway Test. The Psychological Service Center Bulletin, instead of opposite direction.

Pichot, P., López-Ibor, J. \& Valdés, M. (1995). Manual diagnóstico $y$ estadístico de los trastornos mentales (DSM-IV). Barcelona: Masson, S.A.

Pineda, D., Galeano, L., \& Giraldo, Y. (1991). Prueba de memoria semántica con incremento asociativo. Neuropsicología, evaluación clínica y psicometría. Medellín: Prensa Creativa.

Pineda, D., \& Puerta, I. (2001). Prevalencia del trastorno disocial de la conducta en adolescentes usando un cuestionario de diagnóstico epidemiológico. Revista de Neurología, 32, 612-618.

Posada-Villa, J., Aguilar-Gaxiola, S., Magaña, C., \& Gómez, L. (2004). Prevalencia de trastornos mentales y uso de servicios: Resultados preliminares del Estudio Nacional de Salud Mental. Revista Colombiana de Psiquiatría, 33, 241-262.

Rabin, L. A., Barr, W. B., \& Burton, L. A. (2005). Assessment practices of clinical neuropsychologists in the United States and Canada: A survey of INS, NAN, and APA Division 40 members. Archives of Clinical Neuropsychology, 20, 33-65.

Regard, M. (1981). Cognitive rigidity and flexibility: $A$ neuropsychological study. Victoria, B. C.: University of Victoria.

Rey, A., \& Osterrieth, P. A. (1993). Translations of excerpts from Andre Rey's Psychological examination of traumatic encephalopathy and P. A. Osterrieth's The Complex Figure Test. Clinical Neuropsychologist, 7, 2-21.

Rey, C. (2010). Trastorno disocial: Evaluación, tratamiento y prevención de la conducta antisocial en niños y adolescentes. Colombia: Editorial Manual Moderno.

Rosvold, H. E., Mirsky, A. F., Sarason, I., Bransome, E. D., Jr., \& Beck, L. H. (1956). A continuous performance test of brain damage. Journal of Consulting Psychology, 20, 343-350.

Sanabria, A., \& Uribe, A. (2007). Prevalencia de la delincuencia juvenil en Santiago de Cali. Pensamiento Psicológico, 3, 111-122.

Sanabria, A., \& Uribe, A. (2009). Conductas antisociales y delictivas en adolescentes infractores y no infractores. Pensamiento Psicológico, 6, 203-218.

Secretaría de Salud de México (2002). Programa especifico de psicopatología infantil y de la adolescencia 2001-2006. México: Secretaría de Salud de México.

Serper, M., Beech, D. R., Harvey, P. D., \& Dill, C. (2008). Neuropsychological and symptom predictors of aggression on the psychiatric inpatient service. Journal of Clinical and Experimental Neuropsychology, 30, 700-709.

Spreen, O., \& Benton, A. L. (1969). Neurosensory Center Comprehensive Examination for Aphasia. Manual and Instructions. Victoria. B.C.: University of Victoria. 
Strauss, E., Sherman, E. M. S., \& Spreen, O. (2006). A compendium of neuropsychological tests: administration, norms and commentary, 3rd edition. New York: Oxford University Press.

Stroop, J. R. (1935). Studies of interference in serial verbal reactions. Journal of Experimental Psychology, 18, 643-662.

Swanson, L. W. (2000). Cerebral hemisphere regulation of motived behavior. Brain Res, 886, 113-164.

Thapar, A., Button, T., \& McGuffin, P. (2005). Relationship between antisocial behaviour, attention-deficit hyperactivity disorder and maternal prenatal smoking. The British Journal of Psychiatry, $187,155-160$

Thurstone, L. L. (1931). Rank order as a psychological method. Journal of Experimental Psychology, 14, 187-201.
Trujillo, N., Pineda, D., \& Puerta, I. (2001). Alteraciones cognitivas en adolescentes infractores con trastorno disocial de diversos niveles de gravedad. Psicología Conductual, 15, 297-319.

Weiss, L. G., Saklofske, D., Prifitera, A., \& Holdnack, J. (2006). WISC-IV: Advanced clinical interpretation. Burlington, MA: Academic Press.

World Health Organization (1992). Clasificación internacional de enfermedades, décima versión: Trastornos mentales y del comportamiento. Madrid: Meditor.

Yeudall, L. T., Fedora, O., Fedora, S., \& Wardell, D. (1982). Neurosocial perspective on the assessment and etiology of persistent criminally. Australian Journal of Forensic Science, 13, 4. 
